\title{
Antioxidant potential of bitter cumin (Centratherum anthelminticum (L.) Kuntze) seeds in in vitro models
}

\author{
V Ani and Kamatham A Naidu*
}

\begin{abstract}
Background: Bitter cumin (Centratherum anthelminticum (L.) Kuntze), is a medicinally important plant. Earlier, we have reported phenolic compounds, antioxidant, and anti-hyperglycemic, antimicrobial activity of bitter cumin. In this study we have further characterized the antioxidative activity of bitter cumin extracts in various in vitro models.

Methods: Bitter cumin seeds were extracted with a combination of acetone, methanol and water. The antioxidant activity of bitter cumin extracts were characterized in various in vitro model systems such as DPPH radical, ABTS radical scavenging, reducing power, oxidation of liposomes and oxidative damage to DNA.

Results: The phenolic extracts of bitter cumin at microgram concentration showed significant scavenging of DPPH and ABTS radicals, reduced phosphomolybdenum $(\mathrm{Mo}(\mathrm{VI})$ to $\mathrm{Mo}(\mathrm{V}))$, ferricyanide $\mathrm{Fe}(\mathrm{III})$ to Fe(II), inhibited liposomes oxidation and hydroxyl radical induced damage to prokaryotic genomic DNA. The results showed a direct correlation between phenolic acid content and antioxidant activity.
\end{abstract}

Conclusion: Bitter cumin is a good source of natural antioxidants.

Keywords: Bitter cumin Centratherum anthelminticum, polyphenolic compounds, antioxidants, DPPH, ABTS, reducing power, liposomes, oxidative DNA damage

\section{Background}

In living systems, reactive oxygen species (ROS) constitute most important free radicals. ROS include not only oxygen radical, but, also some non radical derivatives of oxygen like $\mathrm{H}_{2} \mathrm{O}_{2}$ [1]. ROS play a positive role in energy production, phagocytosis, and regulation of cell growth, cell signaling and synthesis of biologically important compounds. Oxidative stress is the result of an increased ROS production and/a decrease in their elimination. Based on the fact that ROS are dangerous for cells, tissues and organs it has been inferred that oxidative stress is the cause for number of disorders, including atherosclerosis, neural degenerative disease, inflammation, cancer and ageing [2-4]. The physiological role of antioxidants is to prevent damage to cellular constituents arising as a consequence of chemical reactions involving free radicals

\footnotetext{
* Correspondence: kanaidu@mailcity.com Department of Biochemistry and Nutrition, Central Food Technological Research Institute (Council of Scientific and Industrial Research), Mysore 570020, India
}

$[5,6]$. The use of synthetic antioxidants in food has its beginning in the late 1940's when BHA was found to be effective antioxidant in fatty foods and toxicological studies proved it safe for food use. But, later there are serious concerns over the side effects of these synthetic antioxidants due to their carcinogenic potential [7,8]. As a result there has been a general desire to replace the synthetic food additives with natural antioxidants $[9,10]$.

Phytochemicals are non-nutritive plant chemicals that have protective or disease preventive properties. There are thousands of phytochemicals falling into different groups and one of the most studied groups is phenolics. Plant phenolics are multifunctional and can act as reducing agents, metal chelators and singlet oxygen quenchers. Many studies have shown that phenolics are of great value in preventing the onset and/progression of many human diseases [11-13]. Therefore over the past few years a number of medicinal and food plants are extensively investigated for the presence and activity of polyphenols and other antioxidants [14-16]. There are several 
methods to determine the antioxidant activity of a biological sample each with its own advantages and disadvantages. These tests enable us to examine the possibility of a given biological sample could act as an antioxidant in one or more ways in vivo or in food substances.

Centratherum anthelminticum (L.) Kuntze (bitter cumin) is a member of Asteraceae family of the flowering plants. The seeds have a hot sharp taste; acrid, astringent to the bowls, antihelmintic; cure ulcers, used in skin diseases, leucoderma and fevers. Two novel and two known steroids were isolated respectively from benzene: acetone and ethanolic extracts of the seeds of $C$. anthelminticum [17]. The plant has reported to possess antimicrobial [18], antifilarial [19,20], post-coital anti-implantation [21] and insecticidal activities [22]. Earlier we have reported an array of phenolic compounds, antioxidant activity in few model systems, antimicrobial and anti-hyperglycemic activity of bitter cumin $[23,24]$. The present paper describes antioxidant studies with an emphasis on various in vitro antioxidant model systems.

\section{Methods}

\section{Chemicals}

1,1-Diphenyl -2-picryl hydrazyl (DPPH), 2,2 azinobis-3ethyl benzothiazoline-6-sulfonic acid (ABTS), Butylated hydroxyl anisole (BHA), Ascorbic acid, $\alpha$-Tocopherol, agarose, xylene cyanol, bromophenol blue, ethidium bromide, thiobarbituiric acid and tannic acid were purchased from Sigma chemicals (MO, USA). Bacillus genomic DNA was obtained from the Food Microbiology department of CFTRI. Folin-Ciocalteau reagent, was purchased from Sisco research laboratories (Mumbai, India). Ammonium molybdate, trichloroacetic acid, potassium ferricyanide and ferric chloride were purchased from Qualigens. All other chemicals and solvents used are of analytical grade.

\section{Plant material}

The plant material was purchased from local market and authenticated by National Institute of Science Communication and Information Resources, New Delhi.

\section{Extraction}

The seeds were hand sorted to remove stones and plant debris. The powdered seeds were defatted for 8 hours in Soxhlet's apparatus with hexane. The defatted powder was extracted with methanol:acetone:water (7:7:6) which is subsequently hydrolyzed with $2 \mathrm{~N} \mathrm{HCl}$ and extracted into ethyl acetate and named as Aqueous Methanol Acetone Extract -(AMAECA). The defatted powder was extracted with $80 \%$ methanol and termed as Aqueous Methanol extract (AMECA). The defatted bitter cumin seed powder was extracted with water and named as aqueous extract- $($ AECA) $(1: 10 \mathrm{w} / \mathrm{v} \times 3)$ under continuous stirring at ambient temperature. The organic solvents were removed under vacuum in a rotavapour and water was removed by freeze drying. The solid extract obtained was stored at $4^{\circ} \mathrm{C}$ until use.

\section{Estimation of total phenols}

Total phenol content of the AMAECA, AMECA and AECA were estimated by using Folin-Ciocalteu reagent [25]. $0.5 \mathrm{~mL}$ of the sample dissolved in $\mathrm{MeOH}$ was incubated with $2.5 \mathrm{~mL}$ of $10 \% \mathrm{FC}$ reagent for $2 \mathrm{~min}$ at ambient temperature. To this $2.0 \mathrm{~mL}$ of $7.5 \% \mathrm{Na}_{2} \mathrm{CO}_{3}$ was added and incubated for another 1 hour at ambient temperature. The absorbance of the color developed was measured at $765 \mathrm{~nm}$ against blank developed with 0.5 $\mathrm{mL}$ of solvent using a Shimadzu UV-Visible spectrophotometer (Model- 2100). The total phenolic content was expressed as tannic acid equivalents (TAE) in $\mu \mathrm{g} /$ $\mathrm{mg}$ of the extract, using a standard curve generated with tannic acid. Similarly, the total phenol content was also expressed as gallic acid equivalents (GAE) using a standard curve generated with gallic acid as standard.

\section{In vitro antioxidant activity of bitter cumin extracts $D P P H$ radical scavenging assay}

The antioxidant activity of different extracts of BITTER CUMIN and standard BHA was measured in terms of hydrogen donating or radical scavenging ability using the stable DPPH ${ }^{\circ}$ method Brand Williams et al. 1995 [26]. Briefly $2 \mathrm{ml}$ of $100 \mu \mathrm{M}$ methanolic solution of $\mathrm{DPPH}^{*}$ was incubated with $100 \mu \mathrm{l}$ of bitter cumin extracts or BHA and incubated for a period of $20 \mathrm{~min}$ utes at ambient temperature. At the end of incubation period the OD was measured using a UV-Visible spectrophotometer at $517 \mathrm{~nm}$ against $\mathrm{MeOH}$ blank. $100 \mu \mathrm{l}$ solvent was added to control test tube under the same conditions. The percentage of scavenging or quenching of DPPH radicals $(\mathrm{Q})$ by bitter cumin and BHA was calculated using the following formula.

$$
\mathrm{Q}=100(A 0-A c) / A 0
$$

Where Ao is the absorbance of the control tube Ac is the absorbance of the tube with ' $c$ ' concentration of sample [27]. All the experiments were performed in triplicates.

\section{$\mathrm{ABTS}^{++}$scavenging assay}

Generation of $\mathrm{ABTS}^{*+}$ radical [28] forms the basis of one of the spectrophotometric methods that have been applied to the measurement of the total antioxidant activity of various substances. The experiments were carried out using an improved $\mathrm{ABTS}^{\circ+}$ decolorization assay [29]. ABTS radical cation $\left(\mathrm{ABTS}^{\circ+}\right)$ was produced by reacting ABTS stock solution with $2.45 \mathrm{mM}$ potassium persulfate (final concentration) and allowing the mixture to stand in the dark at 
room temperature for $12-16 \mathrm{~h}$ before use. The ABTS ${ }^{\bullet+}$ solution was diluted to an absorbance of $0.7 \pm 0.05$ at 734 nm (Shimadzu UV-Vis Spectrophotometer) with ethanol. To one ml of $\mathrm{ABTS}^{*+}$ solution different concentrations of bitter cumin extracts/BHA were added. Absorbance was recorded at $1 \mathrm{~min}$ interval up to 7 minutes at $734 \mathrm{~nm}$. All the experiments were performed in triplicates.

\section{Phosphomolybdenum reducing assay}

This assay is based on the reduction of Mo (VI) to Mo (V) by the sample analyte and the subsequent formation of a green phosphate/Mo (V) complex at acidic $\mathrm{pH}$ [30]. The reagent solution consists of $0.6 \mathrm{M} \mathrm{H}_{2} \mathrm{SO}_{4}, 28.0 \mathrm{mM}$ sodium phosphate and $4.0 \mathrm{mM}$ ammonium molybdate. An aliquot of $0.1 \mathrm{ml}$ of sample was combined with $1 \mathrm{ml}$ of reagent solution. The tubes were capped and incubated in a thermal block at $95^{\circ} \mathrm{C}$ for $90 \mathrm{~min}$. After the samples had cooled to room temperature, the absorbance of the aqueous solution of each was measured at $695 \mathrm{~nm}$ against a blank. The blank solution contained 1 $\mathrm{ml}$ of reagent solution and the solvent used for the sample, and it was incubated under the same conditions as the rest of the samples. All the experiments were performed in triplicates. The antioxidant capacity was expressed as equivalents of ascorbic acid. ( $\mu \mathrm{g} / \mathrm{g}$ extract).

\section{Ferricyanide reducing assay}

The reductive potential of the extract was determined according to the method of Oyaizu et al. 1986 [31]. Different concentrations of sample in $0.5 \mathrm{ml}$ of $\mathrm{MeOH}$ were mixed with $2.5 \mathrm{ml}$ of Phosphate buffer $(0.2 \mathrm{M}, \mathrm{pH}$ 6.6 ) and $2.5 \mathrm{ml}$ of $1 \%$ potassium ferricyanide. The mixture was incubated for 20 minutes at $50^{\circ} \mathrm{C}$. At the end of the incubation, $2.5 \mathrm{ml}$ of $10 \%$ trichloroacetic acid was added to the mixture and centrifuged at $5000 \mathrm{rpm}$ for 10 minutes. The upper $2.5 \mathrm{ml}$ layer was mixed with 2.5 $\mathrm{ml}$ of distilled water and $0.5 \mathrm{ml}$ of $0.1 \%$ ferric chloride, and the absorbance was measured at $700 \mathrm{~nm}$ [32]. A higher absorbance of the reaction mixture indicated greater reducing power. Ascorbic acid and BHA were used as a positive control.

\section{Liposome oxidation assay}

The antioxidant activity of the extracts of bitter cumin and $\alpha$-tocopherol in a liposome model system was determined according to the method of Duh and Yen 1997 [33]. Egg lecithin (300 mg) was sonicated with 30 $\mathrm{ml}$ phosphate buffer (10 mM, pH 7.4) in an ultrasonic sonicator for $30 \mathrm{~min}$ to ensure proper liposome formation. Bitter extracts and standards were mixed with the sonicated solution $(0.5 \mathrm{ml}, 10 \mathrm{mg} / \mathrm{ml})$ and incubated for $10 \mathrm{~min}$. at room temperature. The oxidation of liposomes was initiated by adding $\mathrm{FeCl}_{3}(0.5 \mathrm{ml}, 400 \mathrm{mM})$, and ascorbic acid $(0.5 \mathrm{ml}, 400 \mathrm{mM})$. The antioxidative action was measured by the method of Buege and Aust 1978 [34]. The absorbance of the samples was determined at $535 \mathrm{~nm}$ after incubation for $1 \mathrm{~h}$ at $37^{\circ} \mathrm{C}$. The results were expressed as nmol of malondialdehyde (MDA) formed per mg lipid and was calculated by using an extinction coefficient of $1.56 \times 10^{5} \mathrm{M}^{-1} \mathrm{~cm}^{-1}$.

\section{Oxidative DNA damage assay}

Bacterial genomic DNA $(2 \mu \mathrm{g})$ in phosphate buffered saline was incubated with different concentrations of bitter cumin and BHA for 15 minutes at ambient temperature. Oxidation was induced by treating DNA with $1 \mathrm{mM} \mathrm{FeSO}_{4}$ and $10 \mathrm{mM}$ ascorbic acid. Positively controlled reaction was not treated with bitter cumin or oxidative stress and negatively controlled reaction mixture contained $\mathrm{FeSO}_{4}$ and ascorbic acid without any pretreatment with CA. The final reaction volume was 9 $\mu \mathrm{l}$ and the reaction mixture was incubated for 1 hour at $37^{\circ} \mathrm{C}$. The reaction was stopped by adding $3 \mu$ loading buffer (xylene-cyanol, 0.25\%; bromophenol blue, 0.25\%; and glycerol, 30\%) and $9 \mu \mathrm{l}$ of the reaction mixture was loaded on to an agarose gel (1\%). The gel was run in TAE buffer initially for $1 \mathrm{~h}$ at $40 \mathrm{~V}$ followed by 2 hours run at $60 \mathrm{~V}$. The gel was stained with ethidium bromide $(1 \mu \mathrm{g} / \mathrm{ml})$. DNA was visualized and photographed by a digital imaging system (Hero lab, GMBH, Germany).

\section{Statistical analysis}

All the experiments were done in triplicates and expressed as mean \pm S.E.M. The differences in mean values were tested using one-way analysis of variance (ANOVA) and Duncan's multiple range test (DMRT) was used to determine the significant differences amongst the test materials. Differences were considered to be significant at $\mathrm{p} \leq 0.05$.

\section{Results and Discussion \\ Total phenol acids}

Phenols, are a major group of plant metabolites, have profound importance due to their biological properties. The number, type and concentrations of phenols in plants exhibit extreme diversity $[35,36]$. Extraction method and solvent choice are generally critical and no single solvent provides optimum recovery of all phenols. Often a combination of solvents will provide optimum recovery of all phenols or at least a limited range of phenols and with dried materials alcoholic solvents presumably rupture cell membranes and enhance the extraction of endocellular materials [37]. The total phenol content of Bitter cumin seeds was extracted with aqueous methanol-acetone (methanol:acetone:water 7:7:6), $80 \% \mathrm{MeOH}$ and water. The total phenol content was estimated using Folin-Ciocalteu reagent and the values are expressed as gallic acid [25] and tannic acid equivalents (Figure 1). Significant variation in the phenolic content was observed in different extracts of bitter cumin $(\mathrm{p} \leq 0.05)$. Aqueous methanol acetone extract showed highest total phenol content of $551.8 \pm 30.8 \mu \mathrm{g}$ 


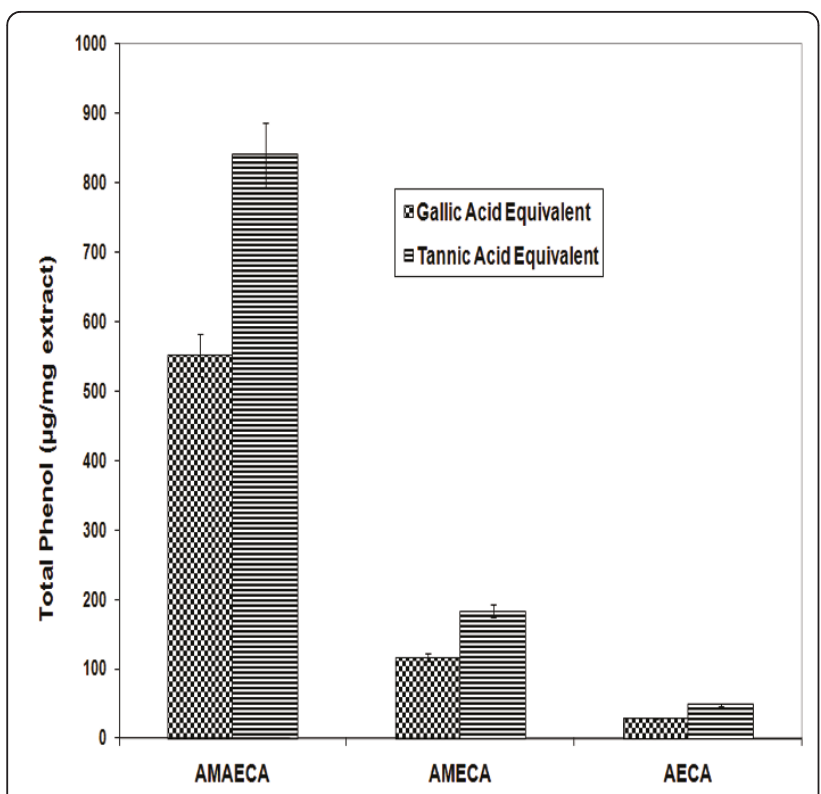

Figure 1 Total phenol content of different extracts of bitter cumin. Values are mean \pm S.E.M. of three experiments.

$\mathrm{GAE} / \mathrm{mg}$ or $840.8 \pm 46.9 \mu \mathrm{g} \mathrm{TAE} / \mathrm{mg})$ and aqueous extract showed lowest total phenolic content of $29.2 \pm$ $1.0 \mu \mathrm{g} \mathrm{GAE} / \mathrm{mg}$ or $48.6 \pm 1.6 \mu \mathrm{g} \mathrm{TAE} / \mathrm{mg}$.

\section{Radical scavenging activity of bitter cumin phenols}

In the DPPH test, the stable, nitrogen centered, coloured, $\mathrm{DPPH}^{*}$ free radical is reduced either by hydrogen donor or antioxidant to a non-radical DPPH-H and the decrease in colour of DPPH radical is monitored over a time period [38]. The kinetics of $\mathrm{DPPH}^{*}$ radicals scavenging activity increased with an increase in the concentration of cumin extract as shown in Figure 2. Addition of bitter cumin extract (AMAECA) showed a sharp drop in DPPH colour intensity, indicating high antioxidant activity in quenching DPPH radicals during the first 30 seconds of the reaction followed by a logarithmic decay. The DPPH ${ }^{*}$ scavenging potential of various bitter cumin extracts and BHA are presented in Figure 3. The correlation coefficient between dose and scavenging percentage are 0.8520, 0.9881, 0.9801 and 0.9475 respectively for BHA, AMAECA, AMECA and AECA. BHA, the synthetic antioxidant showed highest $\mathrm{DPPH}^{*}$ scavenging activity among the tested samples with an $\mathrm{IC}_{50}$ value of $8.2 \pm$ $0.24 \mu \mathrm{g}$. Among various extracts of bitter cumin AMAECA showed highest $\mathrm{DPPH}^{*}$ scavenging activity $\left(\mathrm{IC}_{50} 20.8 \pm 0.18 \mu \mathrm{g}\right.$ ) (Table 1), followed by AMECA $\left(\mathrm{IC}_{50} 191.7 \pm 9.14 \mu \mathrm{g}\right)$ and AECA $\left(\mathrm{IC}_{50} 639.2 \pm 20.91 \mu \mathrm{g}\right)$.

ABTS test is based on the formation of stable, bluegreen coloured $\mathrm{ABTS}^{\bullet+}$ radical for the measurement of the total antioxidant activity of both water-soluble and lipid-soluble antioxidant compounds $[39,40]$. In the

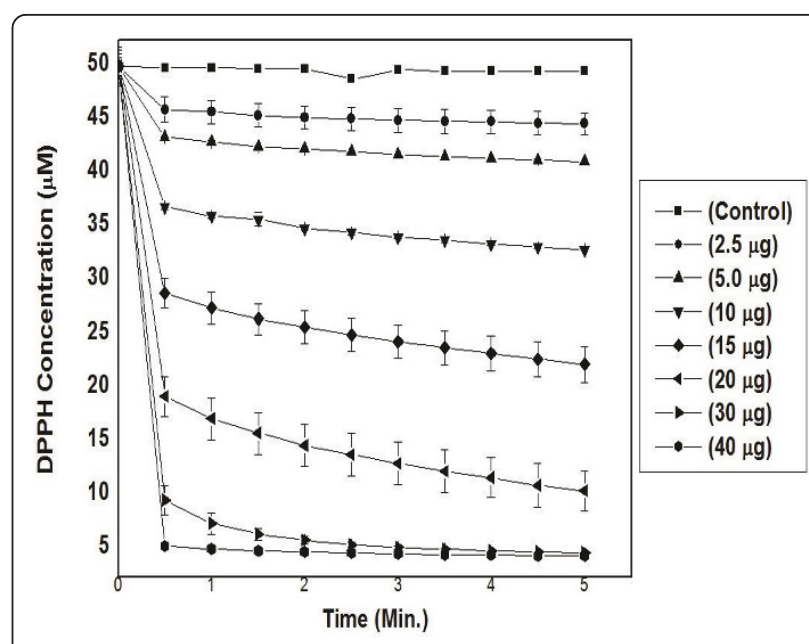

Figure 2 Kinetics of $\mathrm{DPPH}^{*}$ scavenging by different concentrations of bitter cumin extract (AMAECA). Values are mean \pm S.E.M. of three experiments.

presence of an antioxidant the colour production will be suppressed to an extent proportional to the concentration of antioxidants. The kinetics of $\mathrm{ABTS}^{++}$scavenging activity of bitter cumin extract (AMAECA) is presented in Figure 4. ABTS $^{+}$scavenging by AMAECA occurred during first $1 \mathrm{~min}$ of the reaction indicating potent antioxidant activity of bitter cumin. $\mathrm{IC}_{50}$ value for quenching ABTS $^{++}$was found to be 8.3 (Table 1), 47.0 and 68.0 $\mu \mathrm{g}$ for bitter cumin extracts AMAECA, AMECA and AECA, respectively. Thus bitter cumin extracts showed

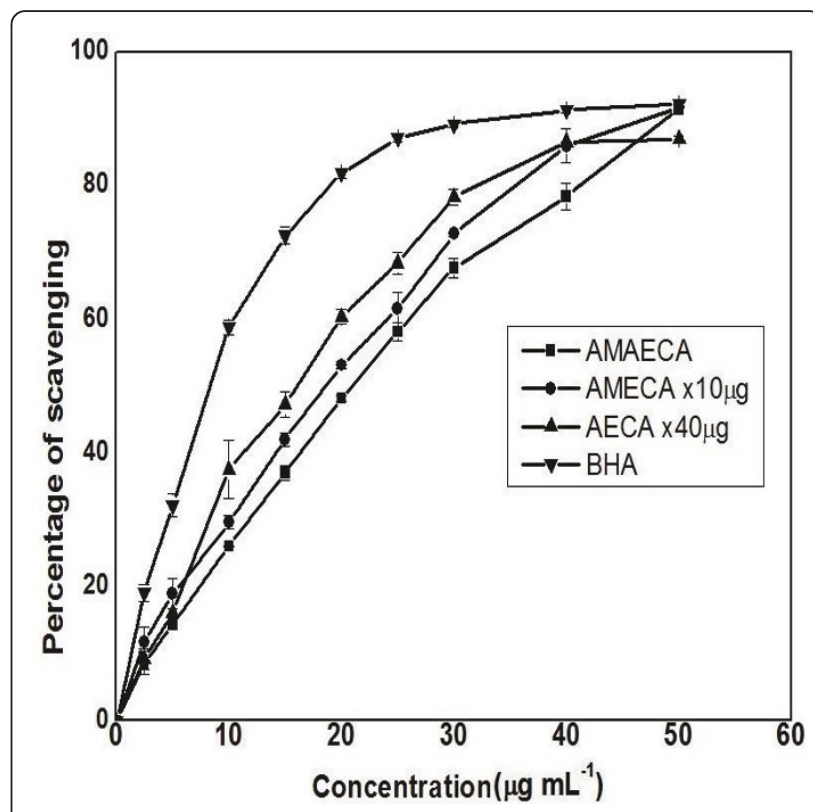

Figure 3 DPPH radical scavenging activity of different extracts of bitter cumin. Values are mean \pm S.E.M. of three experiments. 
Table 1 Antiradical activity of bitter cumin extract (AMAECA)

\begin{tabular}{lcc}
\hline Antiradical assay & $\begin{array}{c}\text { Radical donated/ } \\
\text { scavenged }\end{array}$ & $\begin{array}{c}\text { IC } \\
\mathbf{5 0} \text { values }(\boldsymbol{\mu} \mathbf{g} \text { of } \\
\text { AMAECA) }\end{array}$ \\
\hline $\begin{array}{l}\text { Phosphomolbdenum } \\
\text { reducing power }\end{array}$ & Electron donation & 0.31 \\
$\begin{array}{l}\text { Ferricyanide reducing } \\
\text { Power }\end{array}$ & Electron donation & 0.20 \\
ABTS radical assay & $\mathrm{ABTS}^{++}$ & 8.3 \\
$\begin{array}{l}\text { DPPH radical assay } \\
\text { Liposomal lipid }\end{array}$ & $\mathrm{DPPH}^{*}$ & 20.8 \\
peroxidation & $\mathrm{OH}^{\cdot}$ & 14.3 \\
\hline
\end{tabular}

significant scavenging of DPPH and ABTS radical at $\mu \mathrm{g}$ concentrations.

\section{Reducing power of bitter cumin phenolics}

The reducing power of a compound is associated with electron donating capacity and serves as an indicator of antioxidant activity [41,42]. Phosphomolybdenum reducing power increased with the concentration of bitter cumin extracts as shown in Figure 5. There was a direct relationship between the dose and absorbance. The correlation coefficient of dose versus absorbance was 0.9994, 0.9812, 0.9943 and 0.9957 for BHA, AMAECA, AMECA and AECA respectively. The highest reducing potential was shown by BHA followed by AMAECA, AMECA and AECA. The $\mathrm{IC}_{50}$ value for AMAECA was found to be $0.31 \mu \mathrm{g}$ (Table 1).

Further, the ability of bitter cumin extracts to reduce $\mathrm{Fe}^{3+}$ to $\mathrm{Fe}^{2+}$ was determined and compared with that of a standards BHA and ascorbic acid. All the three bitter cumin extracts showed some degree of electron donating capacity and reduced $\mathrm{Fe}^{3+}$ to $\mathrm{Fe}^{2+}$. All the bitter cumin extracts exhibited lower activity than the standards

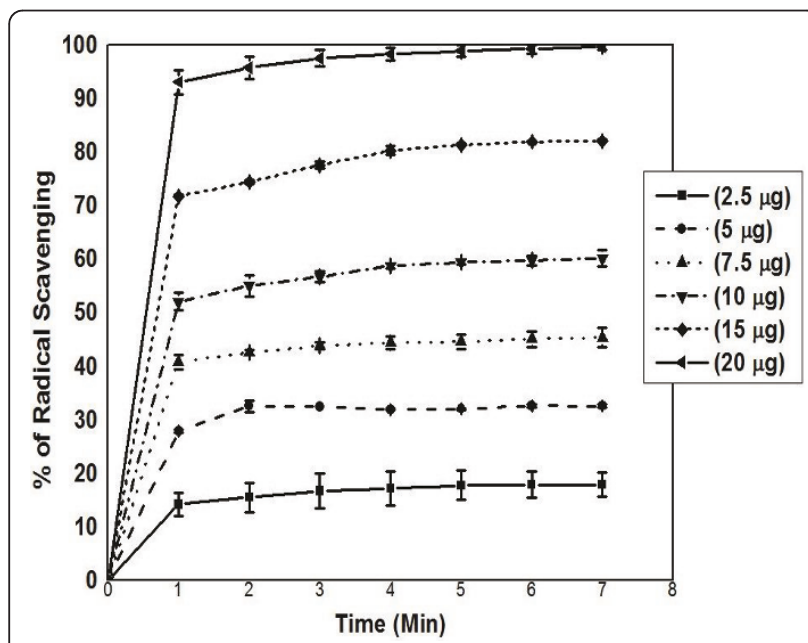

Figure 4 Kinetics of $\mathrm{ABTS}^{*+}$ scavenging of by AMAECA. Values are mean \pm S.E.M. of three experiments.

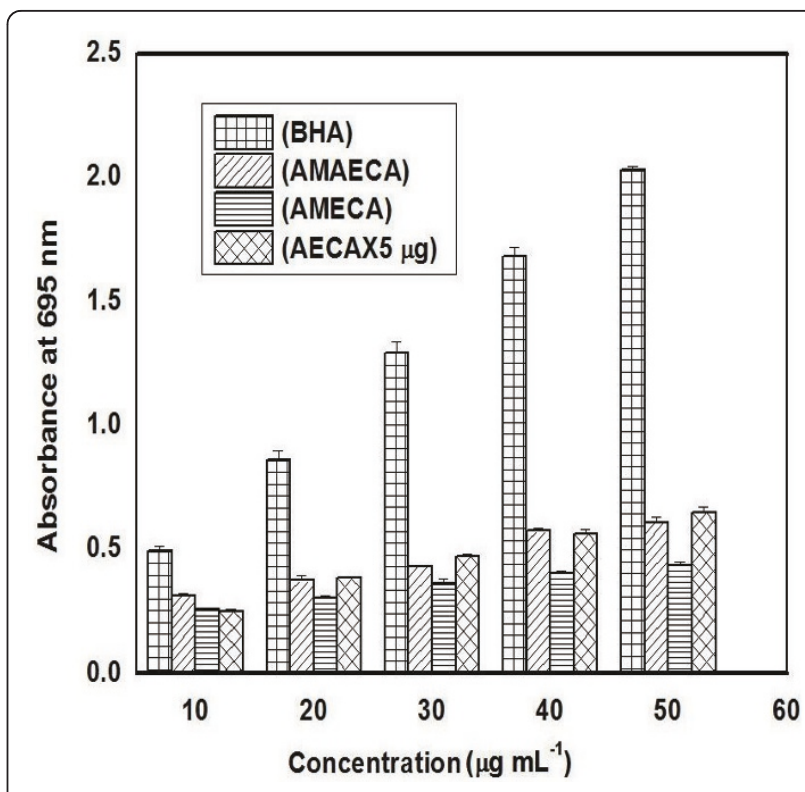

Figure 5 Phosphomolybdenum reducing activity of bitter cumin extracts and BHA. Values are mean \pm S.E.M. of three experiments.

(Figure 6). The correlation coefficient between dose and absorbance was $0.9937,0.9988$ and 0.9878 respectively for Ascorbic acid, BHA and AMAECA. The $\mathrm{IC}_{50}$ value for AMAECA was found to be $0.20 \mu \mathrm{g}$ (Table 1 ).

\section{Inhibition of liposome oxidation activity by bitter} cumin phenols

Cellular membranes, which contain abundant phospholipids, such as phosphatidylcholine (lecithin), are major

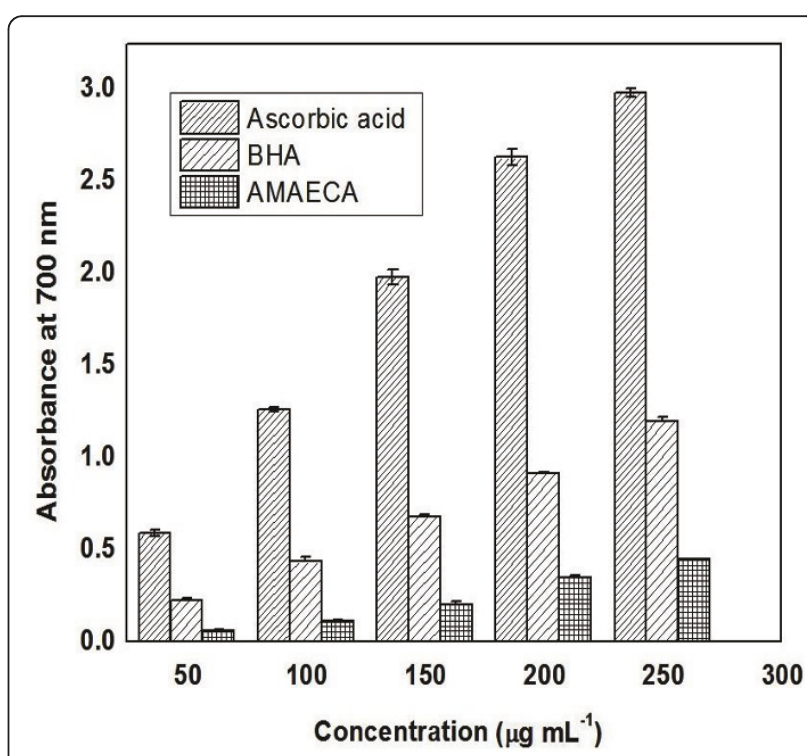

Figure $6 \mathrm{Fe}^{3+}$ reducing power of bitter cumin extract (AMAEC), ascorbic acid and BHA. Values are \pm S.E.M. of three experiments. 
targets of free radicals which induce lipid peroxidation and thereby cause malfunctioning of membranes by altering membrane fluidity and membrane bound enzyme and receptor functions [43]. Further, several toxic byproducts of the peroxidation can damage other biomolecules including DNA away from the site of their generation $[44,45]$. Liposomes are spherical, self closed vesicles of colloidal dimensions, in which (phospho) lipid bilayer sequesters part of the solvent, in which they freely float, into their interior [46]. The use of liposomes appears to be the most promising method of assessing antioxidant properties relevant to human nutrition, since these systems allow investigations of the protection of a substrate by an antioxidant in a model biological membrane or lipoprotein. Figure 7 shows the inhibition of phospholipid peroxidation in presence of bitter cumin extracts and $\alpha$ tocopherol. AMAECA showed highest inhibitory activity and AECA showed lowest activity. All the extracts of bitter cumin showed higher inhibitory activity against phospholipid peroxidation compared to the standard antioxidant $\alpha$-tocopherol. The bitter cumin extracts AMAECA, AMECA, AECA were found to be 41,24 and 3 times more potent than $\alpha$-tocopherol in inhibiting liposome oxidation, respectively. Thus, the efficiency was in the order of AMAECA > AMECA > AECA $>\alpha$-tocopherol. The highest correlation between dose and antioxidant activity was shown by AECA (0.9041) and others showed a correlation

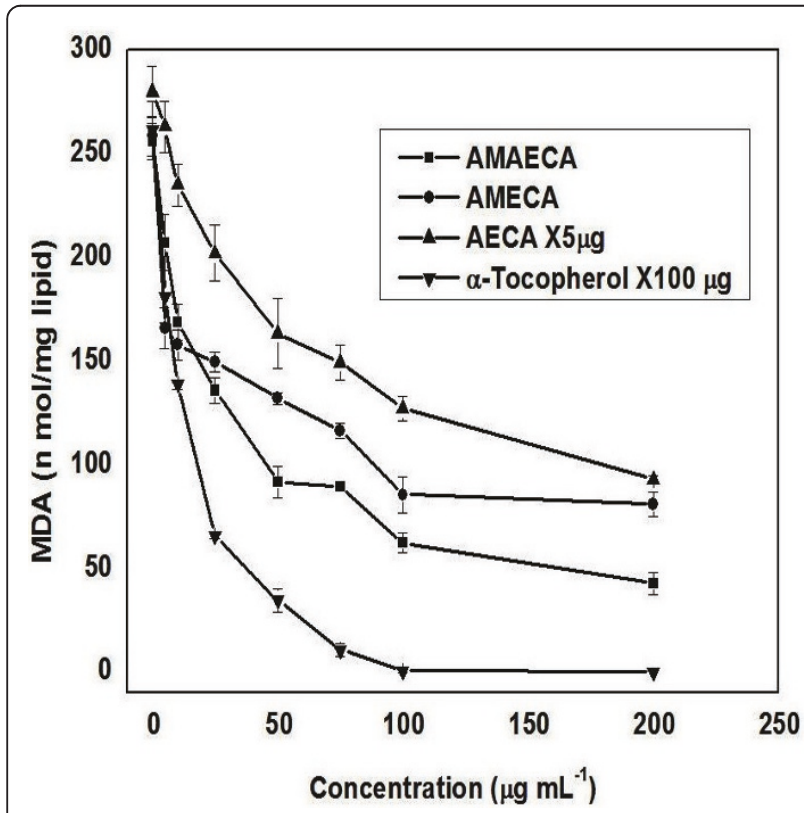

Figure 7 Inhibition of liposomal peroxidation by bitter cumin extracts and $\boldsymbol{\alpha}$-tocopherol. Values are mean \pm S.E.M. of three experiments. coefficient of 0.8288 by AMAECA, 0.7560 by AMECA and 0.7364 by $\alpha$-tocopherol, respectively.

\section{Inhibition of oxidative damage to DNA by bitter cumin phenols}

The most detrimental of the free radicals formed in biological systems is the hydroxyl radical that causes enormous damage on biomolecules of the living cells [47]. DNA is susceptible to oxidative damage and hydroxyl radicals oxidize guanosine or thymine to 8-hydroxyl-2deoxyguanosine and thymine glycol which change DNA and lead to mutagenesis and carcinogenesis [48]. DNA damage results in mutations and altered cell functions. A large proportion of these mutagenic steps precede carcinogenic events. In this study, hydroxyl radicals generated by Fenton reaction were found to induce DNA strand breaks in prokaryotic genomic DNA. Earlier, we reported protection of calf thymus DNA and plasmid DNA (pUC18) against the oxidative damage by bitter cumin extract [23]. In this study, AMAECA was tested for its potential to inhibit the DNA damage induced by hydroxyl radical in prokaryotic genomic DNA. AMAECA at 1.0-2.5 $\mu \mathrm{g}$ offered complete protection to DNA damage in prokaryotic genomic DNA (Figure 8). Thus, the hydroxyl radical quenching ability of extracts of bitter cumin could be responsible for the protection against oxidative damage to DNA.

\section{Conclusion}

The results from various free radical scavenging systems revealed that bitter cumin extracts were strong antioxidants, with different magnitudes of potency in scavenging different ROS at microgram concentrations. The antioxidant activity of bitter cumin significantly correlated with total phenol content of bitter cumin extract. The phenol extract of bitter cumin contained an array of phenolic compounds which may be responsible for its antioxidant activity.

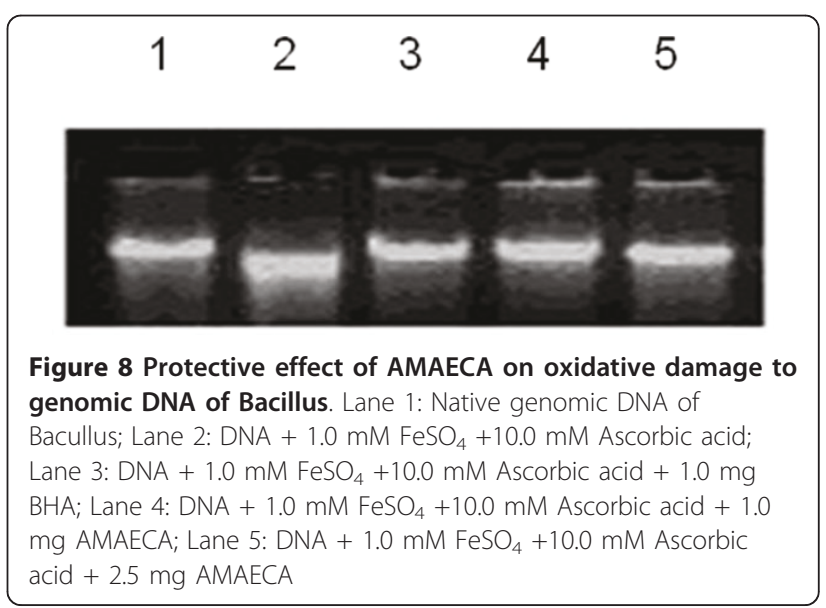




\section{Acknowledgements}

Authors are thankful to Dr. V. Prakash, Director and Dr. P.V. Salimath, Head of the Department of Biochemistry and Nutrition, Central Food Technological Research institute, Mysore for their constant encouragement and support. V. Ani is thankful to the Council of Scientific and Industrial Research (CSIR), New Delhi, for the award of Junior and Senior Research Fellowship. This work was partly supported by a project awarded to KAN by Department of Science and Technology (DST), New Delhi, India.

\section{Authors' contributions}

AV conducted experiments on antioxidant activity of bitter cumin. KAN participated in design of the study and preparation of the manuscript. All the authors read and approved the final manuscript.

\section{Competing interests}

The authors declare that they have no competing interests.

Received: 16 October 2010 Accepted: 20 May 2011

Published: 20 May 2011

\section{References}

1. Halliwell B: Reactive species and antioxidants. Redox biology is a fundamental theme of aerobic life. Plant Physiol 2006, 141:312-322

2. Smith MA, Perry G, Richey PL, Sayre LM, Anderson VE, Beal MF, Kowall N: Oxidative damage in Alzheimer's. Nature 1996, 382:120-121.

3. Finkel T, Holbrook NJ: Oxidants, oxidative stress and the biology of ageing. Nature 2000, 408:239-247.

4. Neumann CA, Krause DS, Carman CV, Das S, Dubey DP, Abraham JL, Bronson RT, Fujiwara Y, Orkin SH, Van Etten RA: Essential role for the peroxiredoxin ( $\operatorname{Prd} 11)$ in erythrocyte antioxidant defence and tumour suppression. Nature 2003, 424:561-565.

5. Gülçin I, Elias R, Gepdiremen A, Boyer L: Antioxidant activity of lignans from fringe tree (Chionanthus virginicus L.). Eur Food Res Technol 2006, 223:759-767.

6. Gülçin I, Elmastaş M, Aboul-Enein HY: Determination of antioxidant and radical scavenging activity of basil (Ocimum basilicum) assayed by different methodologies. Phytother Res 2007, 21:354-361.

7. Grice HP: Enhanced tumour development by Butylated hydroxyanisole (BHA) from the prospective of effect on forestomach and oesophageal squamous epithelium. Food and Chem Toxicol 1988, 26:717-723.

8. Madavi DL, Salunkhe DK: Toxicological aspects of food antioxidants. In Food antioxidants. Edited by: Madavi DL, Deshpande SS, Salunkhe DK. New York: Marcel Dekker Inc; 1995:267.

9. Namiki M: Antioxidants/antimutagens in food. Crit Rev Food Sci Nutr 1990, 29:273-300.

10. Jayaprakasha GK, Jaganmohan Rao L: Phenolic constituents from lichen Parmotrema stuppeum (Nyl.) Hale and their antioxidant activity. Zeitschrift fur Naturforschung 2000, 55c:1018-1022.

11. Halliwell B, Gutteridge JMC: Free Radicals in Biology and Medicine. Clarendon Press, Oxford; 1989.

12. Halliwell B, Gutteridge JMC, Cross CE: Free radicals, antioxidants, and human disease: where are we now? J Lab Clin Med 1992, 119:598-619.

13. Tsao R, Akhtar MH: Nutraceutical and functional foods. I. Current trend in phytochemical antioxidant research. J Food Agric Environ 2005, 3:10-17.

14. Pietta $P G$, Simonetti $P$, Mauri P: Antioxidant activity of selected medicinal plants. J Agric Food Chem 1998, 46:4487-4490.

15. Halvorsen BL, Holte K, Myhrstad MCW, Barikmo I, Hvattum E, Remberg SF, Wold AB, Haffner K, Baugerod H, Andersen LF, Moskaug JO, Jacobs DR, Blomhoff R: A systematic screening of total antioxidants in dietary plants. J Nutr 2002, 132:461-471.

16. Naik GH, Priyadarsini Kl, Satav JG, Banavalikar MM, Sohoni DP, Biyani MK, Mohan $\mathrm{H}$ : Comparative antioxidant activity of individual herbal components used in Ayurvedic medicine. Phytochem 2003, 63:97-104.

17. Mehta BK, Mehta D, Verma M: Novel steroids from the seeds of Centratherum anthelminticum. Nat Prod Res 2005, 19:435-442.

18. Sharma S, Mehta BK: In Vitro antimicrobial efficacy of Centratherum anthelminticum seed extracts. J Hyg Epid Microbiol Immunol 1991, 35:157-161.

19. Singhal KC, Sharma S, Mehta BK: Antifilarial activity of Centratherum anthelminitcum seed extracts on Setaria cervi. Ind J Exper Biol 1992, 30:546-548.
20. Nisha P, Kalyanasundaram M, Paily KP, Abidha PV, Balaraman K: In vitro screening of medicinal plant extracts for macrofilaricidal activity. Parasitol Res 2007, 100:575-579.

21. Sharma S, Mehta BK, Gupta DN: Screening of post-coital antiimplantation activity of Machela champaka (anthers) and Centratherum anthelminticum (seeds). Indian Drugs 1994, 31:280-281.

22. Verma GS, Pandey UK, Pandey M: Note on insecticidal properties of some plants against Bagrada cruciferarum Kirk (Hemiptera: Pentatomidae). Zeitschrift fuer Angewandte Zoologie 1982, 68:109.

23. Ani V, Varadaraj MC, Akhilender Naidu K: Antioxidant and antibacterial activities of polyphenolic compounds from bitter cumin (Cuminum nigrum L.). Eur Food Res Technol 2006, 224:109-115.

24. Ani V, Akhilender Naidu K: Antihyperglycaemic effect of polyphenolic components of black/bitter cumin seeds Centratherum anthelminticum (Willd.) Kuntz. Eur Food Res Technol 2008, 226:897-903.

25. Singleton $\mathrm{VL}$, Rossi JA: Colorimetry of total phenolics with phosphomolybdic-phosphotungstic acid reagents. Amer J Enol Viticul 1965, 16:144-158.

26. Brand-Williams W, Cuvelier ME, Berset C: Use of free radical method to evaluate antioxidant activity. Lebensmittel-Wissenschaft und Technologie 1995, 28:25-30.

27. Gülçin I: Antioxidant activity of L-Adrenaline: An activity-structure insight. Chemi Biol Interact 2009, 179:71-80.

28. Wolfenden BS, Willson RL: Radical cations as reference chromogens in kinetic studies of one-electron transfer reactions: pulse radiolysis studies of 2,20-azinobis-(3-ethylbenzthiazoline-6- sulphonate). J Chem Soc Perkin Trans 1982, 2:805-812.

29. Re R, Pellegrini N, Proteggente A, Pannala A, Yang M, Rice-Evans C: Antioxidant activity applying an improved ABTS radical cation decolorisation assay. Free Rad Biol Med 1999, 26:1231-1237.

30. Prieto P, Pineda M, Aguilar MM: Spectrophotometric quantitation of antioxidant capacity through the formation of a phosphomolybdenum complex: specific application to the determination of vitamin E. Anal Biochem 1999, 269:337-341.

31. Oyaizu M: Studies on product of browning reaction prepared from glucose amine. Japan J Nutr 1986, 44:307-315.

32. Talaz O, Gülçin I, Göksu S, Saracoglu N: Antioxidant activity of 5,10dihydroindeno[1,2-b]indoles containing substituents on dihydroindeno part. Bioorg Med Chem 2009, 17:6583-6589.

33. Du PD, Yen GC: Antioxidative activity of three herbal water extracts. Food Chem 1997, 60:939-645.

34. Buege JA, Aust SD: Microsomal lipid peroxidation. Meth Enzymol 1978, 52:302-310.

35. Hakkinen S, Heinonen M, Karenlampi S, Mykkanen H, Ruuskanen J, Torronen R: Screening of selected flavonoids and phenolic acids in 19 berries. Food Res Inter 1999, 3:345-353.

36. Gorinstein S, Zachwieja Z, Folta M, Barton H, Piotrowiez J, Zemser M, Weisz M, Trukhtenberg S, Martin-Belloso O: Comparative contents of dietary fiber, total phenolics and minerals in persimmons and apples. J Agric Food Chem 2001, 49:952-957.

37. Robards K: Strategies for determination of bioactive phenols in plants, fruit and vegetables. Chromat A 2003, 1000:657-691.

38. Gülçin I: Antioxidant properties of resveratrol: A structure-activity insight. Innovative Food Sci Emer Technol 2010, 11:210-218.

39. Rice-Evans CA, Miller NJ, Paganga G: Structure antioxidant activity relationships of flavonoids and phenolic acids. Free Rad Biol Med 1996, 20:933-956.

40. Miller NJ, Castelluccio C, Tijburg L, Rice-Evans CA: The antioxidant properties of thioflavines and their gallate esters- radical scavengers or metal chelator? FEBS Lett 1996, 392:40-44

41. Siddhuraju P, Mohan PS, Becker K: Studies on the antioxidant activity of Indian laburnum (Cassia fistula L.): a preliminary assessment of crude extracts from stem bark, leaves, flowers and fruit pulp. Food Chem 2002, 79:61-67.

42. Yen GC, Duh PD, Tsai CL: Relationship between antioxidant activity and maturity of peanut hulls. J Agric Food Chem 1993, 41:67-70.

43. Jana AK, Agarwal S, Chatterjee SN: Membrane lipid peroxidation by ultrasound: mechanism and implications. J Biosci 1990, 15:211-215.

44. Box HC, Maccubbin AE: Lipid peroxidation and DNA damage. Nutrition 1997, 13:920-921.

45. Esterbauer $\mathrm{H}$ : Estimation of peroxidative damage: a critical review. Patho Biol Paris 1996, 44:25-28. 
46. Bangham AD, Horne RW: Negative staining of phospholipids and their structured modofication by surface active agents as observed in the electron microscope. J Mol Biol 1964, 8:660-668.

47. Halliwell B: Reactive oxygen species in living systems: Source, biochemistry, and role in human disease. Am J Med 1991, 91:S14-S22.

48. Ames BN, Shigenaga MM, Hagen TM: Oxidants, antioxidants and the degenerative disease of ageing. Proc Nat Acad Sci 1993, 90:7915-7922.

\section{Pre-publication history}

The pre-publication history for this paper can be accessed here: http://www.biomedcentral.com/1472-6882/11/40/prepub

doi:10.1186/1472-6882-11-40

Cite this article as: Ani and Naidu: Antioxidant potential of bitter cumin (Centratherum anthelminticum (L.) Kuntze) seeds in in vitro models. BMC Complementary and Alternative Medicine 2011 11:40.

\section{Submit your next manuscript to BioMed Central} and take full advantage of:

- Convenient online submission

- Thorough peer review

- No space constraints or color figure charges

- Immediate publication on acceptance

- Inclusion in PubMed, CAS, Scopus and Google Scholar

- Research which is freely available for redistribution

Submit your manuscript at www.biomedcentral.com/submit 